\title{
KAPITALISME SOM RELIGION
}

Walter Benjamin, Robert Kurz og Giorgio Agamben

Kapitalisme som religion (forord og redaktion ved Mikkel Bolt og Dominique Routhier, Oversættelse ved Dominique Routhier og Carsten Juel)

Nebula, 2015

86 sider, 98 DKK

At kapitalismen er navnet på en af verdenshistoriens største, voldsomste og mest omsiggribende transformationer af menneskenes sociale liv er det de færreste, der vil benægte. Kapitalens logik - nærmest uanset hvordan denne defineres - har fra sin begyndelse ikke bare forandret samtlige strukturer i de samfund, hvori den opstod, men også samtlige strukturer i samfund, der ellers ikke synes at have haft kimen til kapitalisme i sig. Kapitalen spreder sig med andre ord, og når den spreder sig til forskellige livsfærer (sundhed, uddannelse, fritidsaktiviteter) såvel som til forskellige territorier, omformer den alt eksisterende til at blive en integreret del af kapitalens logik og jagten på profit.

Kapitalen og kapitalismen transformerer altså alt. Spørgsmålet er imidlertid, hvad kapitalisme er? Hvad er dette noget, som transformerer alle sociale forhold overalt på kloden, og som gør - med Marx' og Engels' formulering - at "alt fast og solidt fordufter"?

Disse spørgsmål melder sig, når man læser en ny mini-antologi med titlen $\mathrm{Ka}$ pitalisme som religion. Antologien er en samling af fire korte tekster centreret omkring et lettere obskurt Walter Benjamin-fragment fra 1921, der bærer titlen "Kapitalisme som religion”. Foruden Benjamin-fragmentet indeholder antologien en introduktion af Mikkel Bolt og Dominique Routhier, samt to kritiske kommentarer til Benjamins fragment fra henholdsvis den tyske værdiformsteoretiker Robert Kurz og den italienske filosof Giorgio Agamben. Begge de sidstnævnte forsøger gennem en kritik af Benjamins fragment at videreudvikle Benjamins 'oversete' teori om kapitalismens væsen. 'Overset' i anførselstegn, fordi Benjamins fragment siden førsteudgivelsen i 1985 faktisk har været genstand for et væld af kommentarer. Men dog alligevel overset fordi disse mange kommentarer fuldstændig har overset den "negative totalitet", som med Kurz' ord er på spil i Benjamins forsøg på en fuldstændig og negerende kritik af kapitalismen (s. 54). Men også 'overset' i anførselstegn 
fordi det i Benjamins fragment ikke står helt soleklart, hvad det er for en teori om kapitalisme (som religion), han forsøger at udvikle, og det således kan være lidt svært at se om noget og i så fald hvad, der overhovedet skulle være overset. Antologien fungerer imidlertid ekstremt godt, og med et meget dunkelt udgangspunkt og $\mathrm{i}$ takt med at forskellige pointer gentages, udlægges på forskellige måder, angribes og forsvares, bliver det gradvist mere og mere klart og interessant, hvorledes man kan forstå kapitalisme (som religion). Antologien som helhed præsenterer således ikke tale om én teori om kapitalisme som religion, men derimod forskellige forsøg på at forstå og forklare, hvad kapitalisme er (som religion).

Som både Agamben og Kurz pointerer, er der både interessante indsigter og blindgyder i Benjamins korte fragment. Fragmentet åbner med Benjamins kommentar om, at "[k]apitalismen er at betragte som en religion, dvs. kapitalismen tjener essentielt til at dulme de samme sorger, kvaler, foruroligelser, som de såkaldte religioner engang gav svar på” (s. 35). Man kan læse dette udsagn, som at hverdagslige ritualer som spisning, arbejde og sex, der før blev forstået og praktiseret indenfor en religiøs ramme nu er subsumeret kapitalisme og medieres af markedet og den kapitalistiske logik, med henblik på skabelsen af profit. Imidlertid synes dette udsagn, som både Kurz og Agamben påpeger, at være Benjamins svageste tese om kapitalisme som religion, idet kapitalisme her på en måde blot forstås som en 'erstatning' for religionen snarere end en egentlig kvalitativ forskydning.

Benjamin fremsætter imidlertid også en teori om kapitalismen som væsensforskellig fra andre religioner. Der er fire sådanne træk (om end Benjamin selv starter med at sige, at der er tre - hvilket siger noget om i hvor høj grad Benjamin-fragmentet er en note nedskrevet i skyndingen). For det første, er kapitalismen en ren kultreligion, og der er ikke nogen teologi. For det andet, er der "ikke nogen 'hverdag', ingen dag der ikke ville være festdag" (s. 35). For det tredje, er kapitalismen ikke forsonende, men forskyldende. For det fjerde, må Guden hemmeligholdes. Sagt på en anden måde: Under kapitalismen bliver hverdagen et uendeligt sæt af rituelle handlinger (kultreligion, hver dag som en festdag), som ikke bærer noget løfte om et formål eller frelse som resultat af disse handlinger (ingen teologi, ingen forsoning). Vi går på arbejde, vi transporterer os rundt, vi forbruger, og alt andet i vores liv struktureres efter denne praksis. Disse handlinger forklares ikke og kan ikke forklares med henvisning til noget transcendent eller en dybere mening. I stedet baserer dette handlingsmønster sig på en 'forskyldning' af individet, som op- 
fostres til at føle sig forpligtet til at betale en gæld - 'til samfundet', som man siger som det aldrig har stiftet, og som aldrig endeligt kan tilbagebetales. Denne skyld er med til at sikre, at ritualerne - arbejdsliv, reproduktion - til stadighed opretholdes, selvom der ikke er nogen lovning om forsoning. I modsætning til andre religioner, må Guden således hemmeligholdes, da hemmeligheden er, at der selvfølgelig ikke er nogen Gud, men hvor denne hemmelighed alligevel er nødvendig for at skylden og ritualerne kan opretholdes. Med Benjamins ord: "Guds transcendens er faldet. Men han er ikke død, han er inddraget i menneskeskæbnen" (s. 36). Hvis vi faktisk anerkendte det meningsløse i denne hverdagslige rituelle praksis, ville vi næppe gentage den i det uendelige.

Konklusionen på Benjamins fragment bliver således, at kristendommen i reformationstiden ikke har "begunstiget fremkomsten af kapitalismen [således som Max Weber hævdede], men derimod forvandlet sig til den" (s. 36). Kristendommen er ikke et moralsk kodeks, som skaber kapitalismen. Det er tværtimod sekulariseringen af den kristne religion og kondenseringen af dens kategorier (kult, ritual, skyld, tro, Guds død på korset) til deres reneste form - det vil sige afskrællet fantasien om den transcendente Gud - der er kapitalismen.

Det er denne erkendelse, som går igen i Kurz’ og Agambens artikler. Ifølge Kurz er kapitalismen først og fremmest kendetegnet ved penge-fetichen: troen på denne abstrakte kategori, som dominerer enhver af livets sfærer i det kapitalistiske samfund. Kurz ser dette, som overgangen fra førmoderne penge, Gelt, "i betydningen et offer til guderne", hvor pengene fungerede med reference og tro på noget hinsides, til Geld, "en pervertereret sakral genstand, et absurd sekulariseret sacrum, en som til jorden ankommen alien, slynget ud af sine oprindelige omgivelser, indstiftende en uhørt form for menneskelig fremmedgørelse":

I denne pengenes nye status, som kun var mulig som tautologisk selvreference [...] transformerer de sig fra symbolsk offer-repræsentation til en abstrakt værdirepræsentation, som gennem den blinde menneskelige praksis betingede fremkomsten af det 'abstrakte arbejdes' system. (s. 60)

Hvad Kurz har i tankerne er selvfølgelig Marx' kritik af varens fetichkarakter (og pengenes fetichkarakter), hvorigennem mellem-menneskelige relation og menneskeligt arbejde fejlagtigt opfattes som resultatet af ikke-menneskelige frembringelser, fordi de repræsenteres af ikke-menneskelige fænomener (abstrakt arbejde, penge). Konsekvensen bliver, at menneskene ikke er i stand til at tage kontrol over 
deres egne livsforhold i kollektive beslutningsprocesser, fordi de domineres af og handler med henblik på feticherede abstraktioner såsom først og fremmest pengene. Det er den politiske økonomis metafysiske, men naturaliserede kategorier penge, arbejde, marked, vare - der regerer menneskenes liv (eller hvorigennem de regere deres egne liv), og der er således brug for et opgør med disse kategorier som det metafysiske udgangspunkt for menneskelig livsførelse.

Agamben starter sin artikel med historien om, hvorledes guldstandarden for dollaren blev ophævet af Richard Nixon 15. August 1971: "Fra og med dette øjeblik havde den indskrift, der kan læses på mange pengesedler [...] 'I promise to pay the Bearer on Demand the Sum of X Pounds', underskrevet med centralbankdirektørens signatur, ikke desto mindre mistet sin mening. Nu betød den sætning, at centralbanken $\mathrm{i}$ bytte for den pågældende pengeseddel ville have udleveret til den, der gjorde krav derpå [...] ikke en bestemt mængde guld [...], men en pengeseddel, der var nøjagtig den samme. Pengene var således blevet tømt for enhver anden værdi end den rent selvhenvisende" (s. 77-78). Som Agamben påpeger, er denne overgang ikke blot symptomatisk for en økonomisk begivenhed, men en egentlig ontologisk begivenhed. Penge er ikke længere det samme; de henviser ikke til noget hinsides penge, som man tror har værdi i sig selv (guld, Gud), men henviser kun til sig selv. "Guds transcendens er faldet. Men han er ikke død, han er inddraget i menneskeskæbnen", som vi så Benjamin formulere det.

Agamben knytter denne begivenhed til det græske ord for 'tro' (pistis), som også er det græske ord for kredit, hvilket igen kommer fra det latinske credere: at tro eller at have tillid. Som for Kurz er kapitalismen grundlagt på troen på penge, og eftersom penge med ophævelsen af guldstandarden har afsløret sin reneste form som værende kredit (de henviser kun til hinanden som sig selv), kan kapitalismen beskrives som troen på at tro. "Kapitalismen er en religion, der helt og aldeles er grundlagt på tro; den er en religion hvis tilhængere lever sola fide [alene ved troen]. Og eftersom kapitalismen ifølge Benjamin er en religion, hvor kulten har frigjort sig fra enhver genstand og skylden fra enhver synd, og dermed også fra enhver mulig forløsning, så har kapitalismen ingen genstand ud fra troens synspunkt end på det at tro som ren kendsgerning, på den rene kredit [...], altså på pengene" (s. 82). Vi tror på pengene, hvilket vil sige, at vi tror på kredit, gæld og på skyld og dermed på det system af kredit, gæld og skyld som under kapitalismen strukturere de mellemmenneskelige forhold. 
Alle tekster i antologien lægger således vægt på, at kapitalismen ikke blot er en produktionsmåde eller et særligt klasse- og magtforhold, men at kapitalen afhænger af en særlig form for tro: troen på at tro forstået som troen på kredit forstået som troen på pengene som penge. I den forstand peger de Benjaminske tekster på kapitalismen som en ontologisk eller metafysisk begivenhed og en ontologisk orden, som vi må forstå for at kunne forstå, hvad en ikke-kapitalistisk ordning må være. De diskuterer med andre ord, hvad kapitalismen er, og hvad den er som religion.

Teksterne er muligvis abstrakte, men de spiller godt sammen med andre forsøg på at forstå kapitalisme som andet end blot en økonomisk-politisk konstellation og i stedet som en antropologisk eller ontologisk struktur. Her tænker jeg særligt på David Graebers Debt: The First 5,000 Years og Maurizio Lazzaratos Making of the Indebted Man og Governing by Debt, som på mange måder supplerer diskussionerne fundet i Kapitalisme som religion. Sammen med disse tekster stiller antologien spørgsmålet: Er der metafysiske kategorier eller en bestemt form for metafysik, som er nødvendig for opretholdelsen af kapitalismen?

Tilbage i 1847/8 hævdede Marx og Engels at "alt fast og solidt fordufter, alt helligt bliver klædt af, og menneskene bliver endelig tvunget til at se nøgternt på deres egen stilling i tilværelsen, på deres indbyrdes forhold". Hvad denne antologi viser er, at menneskene ikke nødvendigvis bliver tvunget til at se nøgternt på deres stilling i tilværelsen blot fordi alt helligt bliver klædt af. Tværtimod har kapitalismen formået at overleve som religion. Dermed er det nødvendigt med en genoplivet religionskritik af kapitalismen som religion før end at de metafysiske forudsætninger for en kommunistisk orden kan finde sted.

Nicolai von Eggers 